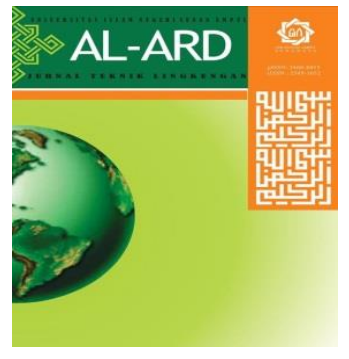

Al-Ard: Jurnal Teknik Lingkungan

Vol.5 No.2 - Maret 2020(hal. 107-115)

http://jurnalsaintek.uinsby.ac.id/index.php/alard/index
Al-Ard:

Jurnal

Teknik Lingkungan

\title{
Pengaruh Waktu Tinggal dan Media Tanam pada Constructed Wetland untuk Mengolah Air Limbah Industri Tahu Muhammad Al Kholif ${ }^{1}$, Pungut ${ }^{2}$, Sugito ${ }^{3}$, Joko Sutrisno ${ }^{4}$, Winda Sulistyo Dewi ${ }^{5}$ \\ 1,2,3,4,5Universitas PGRI Adi Buana (UNIPA) Surabaya, Indonesia \\ alkholif87@unipasby.ac.id
}

\begin{abstract}
Tofu industry waste pollution is still a serious problem. The high burden of tofu industrial waste pollutants is still a major problem. besides, the unavailability of the budget for processing and the limitations of a cheap and efficient treatment system are factors supporting the pollution of tofu waste in the environment. This study examines the efficiency of reducing $\mathrm{BOD}_{5}$ and $\mathrm{COD}$ treated with constructed wetlands using water jasmine plants (Enchinodorus palaefolius). The system used is the wetland subsurface with continuous flow. The media used include sand and biochar with a residence time of 12 hours 18 hours. Whereas pH, temperature, and flow rate are conditioned as control variables. The greatest efficiency of BOD $_{5}$ and COD occurs in reactors using biochar media and a residence time of 18 hours with an efficiency of BOD 5 of $50.52 \%$ and COD of $55.02 \%$.
\end{abstract}

Keyword: Constructed Wetland, BOD, COD, Media, Hydraulic Retention Time

\begin{abstract}
Abstrak
Pencemaran limbah industri tahu masih menjadi masalah yang serius. Tingginya beban pencemar limbah industri tahu masih menjadi masalah utama. Selain itu tidak tersedianya anggaran untuk pengolahan serta keterbatasan sistem pengolahan yang murah dan efisien menjadi faktor pendukung pencemaran limbah tahu pada lingkungan. Penelitian ini mengkaji efisiensi penurunan BOD5 dan COD yang diolah dengan constructed wetland menggunakan tanaman melati air (Enchinodorus palaefolius). Sistem yang digunakan adalah subsurface wetland dengan aliran continue. Media yang digunakan meliputi pasir dan biochar dengan waktu tinggal 12 jam 18 jam. Sedangkan $\mathrm{pH}$, suhu, dan debit aliran dikondisikan sebagai variabel kontrol. Efisiensi BOD5 dan COD terbesar terjadi pada reaktor yang menggunakan media biochar dan waktu tinggal 18 jam dengan efisiensi BOD5 sebesar 50,52\% dan COD sebesar 55,02\%.
\end{abstract}

Kata Kunci: Constructed Wetland, BOD, COD, Media Tanam, Waktu Tinggal

\section{PENDAHULUAN}

Dunia industri dewasa ini telah mengalami perkembangan yang cukup pasat. Selain berdampak positif dengan memberikan sumbangan besar terhadap perekonomian, industri juga memberikan dampak negatif seperti penurunan kualitas lingkungan. Salah satu industri yang sedang berkembang saat ini adalah industri tahu. Perkembangannya terlihat dari tingginya konsumsi tahu oleh masyarakat yang mencapai $0,157 \mathrm{~kg}$ pada tahun 2017 dan 0,158 kg per kapita dalam seminggu pada tahun 2018 (BPS, 2019).

Permasasahan yang sering muncul terkait industri tahu adalah masalah pengolahan limbah, dimana limbah tahu memiliki kandungan pencemar seperti BOD sebesar 5000-10.000 mg/L dan COD 7000$12.000 \mathrm{mg} / \mathrm{L}$ serta tingkat kemasaman yang sangat rendah, yaitu 4-5 (Hikmah, 2016). Nilai tersebut tentunya sangat jauh dari standard baku mutu yang ditetapkan, sehingga sangat berbahaya jika dibuang langsung ke lingkungan. Selain itu sebagian besar industri tahu masih merupakan industri kecil skala rumah tangga, yang mana tidak tersedia anggaran yang cukup untuk mengolah limbah tahu yang dihasilkan. Keterbatasan sistem pengolahan air limbah yang murah dan efisien 
juga menjadi kendala dalam mengolah limbah industri tahu.

Constructed wetland merupakan sistem pengolahan air limbah yang efisisen, sederhana, murah, dan mudah dioperasikan karena prinsipnya meniru prinsip alamiah yang terjadi di lahan basah alami seperti rawarawa dan laguna (Gupta et al., 2016). Menurut (Y. Zhang, 2012), sistem ini didesain dengan memanfaatkan proses alamiah yang melibatkan tumbuhan, media, dan mikroorganisme yang saling berinteraksi dimana mikroorganisme nantinya akan menempel pada akar tanaman air sedangkan tanaman air menghasilkan oksigen yang diperlukan oleh mikroorganisme sehingga tercipta kondisi aerobik yang mendukung penguraian tersebut.

Tanaman yang akan diterapkan dalam proses fitoremediasi adalah melati air (Echinodorus palaefolius). Hal itu dikarenakan pertumbuhannya yang mudah dan cepat sehingga nantinya saat digunakan pada sistem constructed wetland dapat beradaptasi dengan mudah. Selain tanaman, media tanam juga memiliki peran penting dalam proses constructed wetland. Media tanam merupakan tempat tumbuh tanaman sekaligus berinteraksi langsung dengan polutan melalui proses penyerapan. Berbagai media buatan telah diuji untuk meningkatkan kemampuan constructed wetland, namun untuk menemukan media filter yang sesuai dengan biaya rendah dalam sistem constructed wetland merupakan masalah penting. Salah satu media yang sedang diupayakan saat ini adalah biochar. Menurut (Gupta et al., 2016) biochar merupakan limbah biomassa pertanian yang multifungsi untuk aplikasi pertanian dan lingkungan serta memiliki kemampuan untuk memulihkan kontaminan organik dan anorganik. Selain itu biochar diketahui memiliki struktur yang sangat berpori, mengandung berbagai gugus fungsi dan terbukti efektif dalam adsorpsi logam berat (D. Q. Zhang et al., 2014).

Penelitian yang dilakukan (Gupta et al., 2016) menggunakan media biochar tempurung kelapa dalam waktu tinggal 3 hari diketahui memiliki efisiensi penghilangan COD sebesar 91,3\%. Sedangkan (Vijay et al., 2017) diketahui efisiensi penyisihan BOD dan COD yang menggunakan media campuran biochar dan tanah dengan waktu tinggal 24 jam masing-masing adalah $95 \%$ dan $86 \%$.
Penelitian lain yang dilakukan (Pungut \& Al Kholif, 2016), diketahui constructed wetland yang berbentuk parit dengan media tanam pasir kasar dan bertanaman keladi air, serta menggunakan waktu tinggal 24 jam.

Proses ini akan membandingkan efisiensi penggunaan pasir dan biochar sebagai media tanam dengan waktu tinggal 12 jam dan 18 jam serta menggunakan tanaman melati air (Echinodorus palaefolius) terhadap penurunan kadar COD dan BOD pada limbah cair industri tahu. Diketahui waktu tinggal 18 jam dengan media biochar mampu menyisihkan beban pencemar lebih tinggi yaitu $\mathrm{BOD}_{5}$ sebesar $50,52 \%$ dan COD sebesar $55,02 \%$.

\section{METODE PENELITIAN}

Penelitian ini merupakan penelitian eksperimen terapan untuk mengetahui kemampuan tanaman melati air dalam sistem constructed wetland pada media pasir dan biochar dalam menurunkan kandungan BOD dan COD air limbah industri tahu. Rancangan penelitian digambarkan seperti pada gambar1.

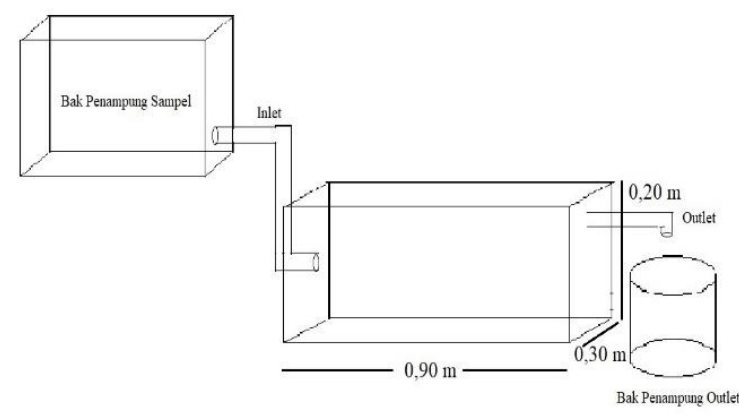

Gambar 1 Desain Sistim Pengolahan Air Limbah

Sistem constructed wetland yang digunakan adalah sistim subsurface wetland dengan aliran continue dan menggunakan tanaman melati air (Echinodorus palaefolius). Waktu tinggal yang digunakan yaitu 12 jam dan 18 jam dengan debit aliran $0,0027 \mathrm{~m}^{3} / \mathrm{jam}$ baik pada inlet maupun outlet. Media tanam yang digunakan yaitu pasir yang mempuyai diameter 2-5 $\mathrm{mm}$ dan biochar. Biochar yang digunakan dalam penelitian ini dibeli dari pasar lokal. Ukuran partikel bervariasi dengan permukaan kasar dan heterogen. Hasil uji porositas didapatkan porositas media pasir adalah 0,48 sedangkan media biochar 0,60. Reaktor yang digunakan terbuat dari kaca dengan ketebalan $5 \mathrm{~mm}$. Untuk memperoleh dimensi ukuran reaktor dilakukan perhitungan sebagai berikut: 
Volume air limbah yang masuk pada wetland

$V=Q \times t d$

Sehingga:

a. Waktu Tinggal 12 Jam

$\mathrm{V}=0,0027 \mathrm{~m}^{3} / \mathrm{jam} \times 12 \mathrm{jam}=0,0324 \mathrm{~m}^{3}$

b. Waktu Tinggal $18 \mathrm{Jam}$

$\mathrm{V}=0,0027 \mathrm{~m}^{3} / \mathrm{jam} \times 18 \mathrm{jam}=0,0486 \mathrm{~m}^{3}$

Volume reaktor yang dibutuhkan diperoleh dengan memperhatikan hasil uji porositas media yang digunakan. Adapun volume reaktor yang dibutuhkan sebagai berikut:

V Reaktor $=\frac{V_{\text {air yang masik ke wetland }}}{\text { Porositas }_{\text {Media }}}$

Sehingga:

a. Reaktor A: Media Pasir - Waktu Tinggal 12 Jam

$$
\mathrm{V}=\frac{0,0324 \mathrm{~m}^{3}}{0,48}=0,0675 \mathrm{~m}^{3}
$$

b. Reaktor B: Media Pasir - Waktu Tinggal 18 Jam

$\mathrm{V}=\frac{0,0486 \mathrm{~m}^{3}}{0,48}=0,10125 \mathrm{~m}^{3}$

c. Reaktor C: Media Biochar Sekam Padi Waktu Tinggal 12 Jam

$\mathrm{V}=\frac{0,0324 \mathrm{~m}^{3}}{0,60}=0,054 \mathrm{~m}^{3}$

d. Reaktor D: Media Biochar Sekam Padi Waktu Tinggal 18 Jam

$\mathrm{V}=\frac{0,0486 \mathrm{~m}^{3}}{0,60}=0,081 \mathrm{~m}^{3}$

Ukuran reaktor dibuat sesuai dengan hasil perhitungan volume reaktor yang dibutuhkan. Dalam penelitian ini digunakan 4 buah reaktor. Panjang dan lebar setiap reaktor yang digunakan adalah sama, berturut-turut yaitu $0,90 \mathrm{~m}$ dan $0,30 \mathrm{~m}$. Adapun tinggi reaktor sesuai perhitungan berikut:

$t=\frac{V}{P \times l}$

Sehingga:

a. Reaktor A: Media Pasir - Waktu Tinggal 12 Jam

$$
\mathrm{t}=\frac{0,0675 \mathrm{~m}^{3}}{0,90 \mathrm{~m} \times 0,30 \mathrm{~m}}=0,25 \mathrm{~m}
$$

b. Reaktor B: Media Pasir - Waktu Tinggal 18 Jam

$\mathrm{t}=\frac{0,10125 \mathrm{~m}^{3}}{0,90 \mathrm{~m} \times 0,30 \mathrm{~m}}=0,375 \mathrm{~m}$ c. Reaktor C: Media Biochar Sekam Padi Waktu Tinggal 12 Jam

$$
\mathrm{t}=\frac{0,054 \mathrm{~m}^{3}}{0,90 \mathrm{~m} \times 0,30 \mathrm{~m}}=0,20 \mathrm{~m}
$$

d. Reaktor D: Media Biochar Sekam Padi Waktu Tinggal 18 Jam

$$
\mathrm{t}=\frac{0,081 \mathrm{~m}^{3}}{0,90 \mathrm{~m} \times 0,30 \mathrm{~m}}=0,30 \mathrm{~m}
$$

Berdasarkan hasil perhitungan diatas maka diperoleh ukuran masing-masing reaktor sebagai berikut:

Reaktor $A=0,90 \mathrm{~m} \times 0,30 \mathrm{~m} \times 0,25 \mathrm{~m}$

Reaktor $\mathrm{B}=0,90 \mathrm{~m} \times 0,30 \mathrm{~m} \times 0,375 \mathrm{~m}$

Reaktor $\mathrm{C}=0,90 \mathrm{~m} \times 0,30 \mathrm{~m} \times 0,20 \mathrm{~m}$

Reaktor $\mathrm{D}=0,90 \mathrm{~m} \times 0,30 \mathrm{~m} \times 0,30 \mathrm{~m}$ Berikutnya tahap aklimatisasi tanaman, dilakukan dengan tujuan agar tanaman bisa beradaptasi dengan air limbah dan media tanam yang baru. Tanaman melati air diseleksi berdasarkan kriteria yaitu melati air yang berumur lebih kurang 2 bulan dengan kesamaan ukuran batang dan daun tanaman, selanjutnya dicuci dan dilakukan aklimatisasi. Aklimatisasi tanaman berlangsung selama \pm 14 hari dengan kriteria 2 hari menggunakan air bersih, 4 hari menggunakan 25\% air limbah, 4 hari menggunakan 50\% air limbah, dan 4 hari menggunakan $100 \%$ air limbah. Tanda proses aklimatisasi telah berlangsung adalah dengan adanya perubahan morfologi pada daun, batang, dan akar. Adapun $\mathrm{pH}$ dan suhu optimum untuk pertumbuhan tanaman melati air adalah $\mathrm{pH}$ 4,5-7 dengan rentang suhu antara $25-35^{\circ} \mathrm{C}$ (Setiyanto et al., 2016).

Setelah semua proses telah dilakukan, selanjutnya dilakukan proses Constructed Wetland, air limbah tahu dilewatkan di dalam Constructed Wetland melalui bak penampung sampel dalam rentang suhu $25-35{ }^{\circ} \mathrm{C}$ dan $\mathrm{pH}$ 4,5-7. Laju aliran rata-rata yang digunakan adalah $0,0027 \mathrm{~m}^{3} / \mathrm{jam}$ untuk setiap unit reaktor. Sampel air hasil perlakuan dikumpulkan setiap 12 jam dan 18 jam dengan pengulangan sebanyak 5 kali. Kemudian dibawa ke laboratorium yang telah ditentukan untuk dianalisa kadar $\mathrm{BOD}_{5}$ dan COD. Efisiensi penurunan beban pencemar dihitung menggunakan rumus berikut:

Penurunan $(\%)=\frac{C o-C i}{C o} \times 100 \%$

Dimana:

$\mathrm{Co}=$ Konsentrasi $\mathrm{BOD}_{5} / \mathrm{COD}$ Inlet

$\mathrm{Ci}=$ Konsentrasi $\mathrm{BOD}_{5} / \mathrm{COD}$ Outlet 


\section{HASIL DAN PEMBAHASAN \\ Karakteristik Awal Limbah Tahu}

Sampel air limbah yang digunakan dalam penelitian merupakan limbah cair industri tahu yang diperoleh dari home industri yang berada di Desa Kemantren RT 06 RW 01 Kecamatan Tulangan, Sidoarjo. Kondisi fisik air limbah yaitu berwarna kuning keruh, berbau asam, dan terdapat gumpalangumpalan ampas tahu berukuran kecil. Untuk digunakan dalam penelitian ini, dilakukan pengolahan awal pada limbah cair industri tahu yaitu penyaringan sederhana. Dari data awal diperoleh kadar BOD sebesar 1899,9 mg/L dan kadar COD sebesar 4895,9 mg/L. Nilai pH pada semua reaktor rata-rata berkisar antara 6,4-6,6 dengan kadar suhu antara $25,5-27,1{ }^{\circ} \mathrm{C}$ pada inlet dan antara $25,7-26,9^{\circ} \mathrm{C}$ pada outlet.

\section{Aklimatisasi Tanaman}

Proses aklimatisasi bertujuan agar tanaman dapat menyesuaikan diri dengan air limbah dan media tanam yang baru. Tanaman melati air diseleksi berdasarkan kriteria yaitu melati air yang berumur kurang lebih 2 bulan dengan kesamaan ukuran batang dan daun tanaman. Adapun tanaman melati air yang digunakan memiliki panjang batang kurang lebih $50 \mathrm{~cm}$ dengan panjang daun antara 20$27 \mathrm{~cm}$. Masing-masing reaktor terdiri dari 3 buah tanaman melati air dengan jumlah batang untuk masing-masing tanaman antara 5-7 tangkai, sedangkan diameter masingmasing batang antara $0,5-1 \mathrm{~cm}$.

Proses Aklimatisasi tanaman berlangsung selama 14 hari dengan kriteria 2 hari menggunakan air bersih, 4 hari menggunakan $25 \%$ air limbah, 4 hari menggunakan $50 \%$ air limbah, dan 4 hari menggunakan $100 \%$ air limbah. Proses aklimatisasi dikatakan selesai manakala ada pertumbuhan tunas baru atau adanya perubahan morfologi pada daun, batang, dan akar. Adapun $\mathrm{pH}$ dan suhu optimum untuk pertumbuhan tanaman melati air adalah $\mathrm{pH}$ 4,5-7 dengan rentang suhu antara 25-35 ${ }^{\circ} \mathrm{C}$ (Setiyanto et al., 2016). Pengukuran $\mathrm{pH}$ dan suhu dilakukan setiap hari yaitu sebelum melewati reaktor untuk inlet dan setelah melewati reaktor untuk outlet.

Secara keseluruhan nampak nilai $\mathrm{pH}$ dan suhu selama proses aklimatisasi tanaman merupakan nilai $\mathrm{pH}$ dan suhu optimum untuk pertumbuhan tanaman melati air. Seperti hal nya hasil yang diperoleh oleh (Setiyanto et al., 2016), nilai $\mathrm{pH}$ dan suhu selama proses aklimatisasi tanaman adalah $\mathrm{pH}$ 6,2 dengan suhu antara $29^{\circ} \mathrm{C}$, yang menandakan bahwa kondisi lingkungan berlangsung baik.

\section{Pengukuran Variabel Kontrol}

Pengukuran variabel kontrol dilakukan agar variabel kontrol tidak memberikan pengaruh terhadap pengolahan. Variabel kontrol dalam penelitian ini yaitu:

a. $\mathrm{pH}$

Perubahan $\mathrm{pH}$ mempengaruhi pertumbuhan mikroorganisme karena sebagian besar mikroorganisme tidak dapat mentoleransi level $\mathrm{pH}$ di bawah 4,0 atau pH di atas 9,5 (Kaswinarni, 2007). Selain itu dalam sistem constructed wetland nilai $\mathrm{pH}$ yang diharapkan adalah netral atau mendekati netral, karena dengan nilai $\mathrm{pH}$ netral akan berpengaruh terhadap proses fotosintesis tanaman dan aktivitas mikroorganisme dalam air limbah (Sari et al., 2015) Pengukuran $\mathrm{pH}$ pada penelitian ini dilakukan dengan menggunakan $\mathrm{pH}$ meter dan dilakukan pada saat pengambilan sampel inlet maupun outlet.

Secara keseluruhan nampak nilai $\mathrm{pH}$ dari semua reaktor baik inlet maupun outlet adalah konstan, tidak ada perubahan nilai $\mathrm{pH}$ secara drastis. Nilai $\mathrm{pH}$ cenderung netral dengan rentang antara 6,3-6,6. Hasil tersebut sejalan dengan hasil penelitian (Ratnawati \& Talarima, 2017) yang mana diperoleh nilai $\mathrm{pH}$ influen dan effluen adalah $\mathrm{pH}$ 7. Dengan nilai $\mathrm{pH}$ air limbah yang netral menandakan bahwa kondisi lingkungan dalam sistem constructed wetland berlangsung baik.

b. Suhu

Pengukuran suhu penting dilakukan pada air limbah, karena proses pengolahan secara biologi terjadi pada kondisi mesofilik dengan kisaran suhu yaitu antara 20-45 ${ }^{\circ} \mathrm{C}$. Kondisi mesofilik merupakan kondisi suhu yang optimum untuk menguraikan bahan organik, sehingga perlu dipertahankan secara konstan (Kaswinarni, 2007). Suhu air limbah nantinya akan berpengaruh pada akitivitas mikroorganisme maupun tanaman, sehingga akan mempengaruhi kinerja pengolahan air limbah yang masuk ke dalam reaktor constructed wetland yang akan digunakan (Astuti et al., 2017). Selain 
itu untuk pertumbuhan tanaman melati air sendiri kondisi optimumnya yaitu $25-35^{\circ} \mathrm{C}$ (Setiyanto et al., 2016). Pengukuran suhu pada penelitian ini dilakukan pada saat pengambilan sampel inlet maupun outlet dan diukur menggunakan thermometer.

Secara keseluruhan nampak nilai suhu dari semua reaktor baik inlet maupun outlet adalah konstan, tidak ada perubahan nilai suhu secara drastis. Nilai suhu normal dengan rentang antara $25,6-27,1^{\circ} \mathrm{C}$. Hasil tersebut sejalan dengan hasil penelitian (Ratnawati \& Talarima, 2017) yang mana diperoleh nilai suhu pada influen dan effluen berkisar antara $27-29^{\circ} \mathrm{C}$, yang menandakan bahwa kondisi lingkungan dalam sistem constructed wetland berlangsung baik.

c. Debit

Pengukuran debit dilakukan menggunakan stopwatch dan gelas ukur 50 mL. Debit air limbah pada penelitian ini yaitu $\quad 0,0027 \quad \mathrm{~m}^{3} / \mathrm{jam}$. Untuk mempermudah pengukuran maka debit air limbah dikonversi menjadi $45 \mathrm{~mL} /$ menit. Diketahui nilai debit baik inlet maupun outlet masing-masing reaktor menunjukkan nilai yang konstan dengan kisaran 43,5-45,5 $\mathrm{mL} /$ menit, sehingga pengaturan debit pada masing-masing reaktor sudah sesuai dengan perencanaan.

\section{Analisa Kadar $\mathrm{BOD}_{5}$ dan $\mathrm{COD}$}

Proses pengolahan dimulai dengan mengalirkan limbah cair industri tahu ke dalam reaktor secara continue. Pengambilan sampel inlet dan outlet dilakukan sesuai variasi variabel bebas yaitu 12 jam dan 18 jam baik pada media pasir maupun media biochar. Masing-masing variasi variabel bebas dilakukan pengulangan sebanyak 5 kali. Selanjutnya sampel inlet dan outlet yang didapat di analisis kadar BOD $_{5}$ sesuai metode uji titrimetri (SNI 06-6989.72-2009). Adapun efisiensi kadar $\mathrm{BOD}_{5}$ pada reaktor $\mathrm{A}$ dapat dilihat pada Gambar 1.

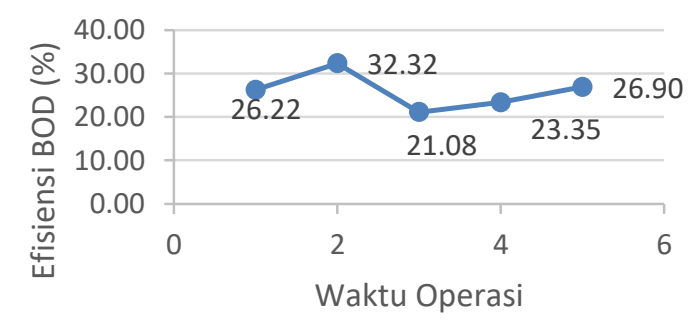

Gambar 1 Grafik Efisisensi Penyisihan Kadar BOD 5 pada Reaktor A
Gambar 1 menunjukan adanya penurunan pada kadar $\mathrm{BOD}_{5}$ tertinggi terjadi pada waktu operasi 12 jam ke-2 dengan efisiensi penyisihan sebesar $32,32 \%$. Hal ini menunjukkan bahwa pada waktu operasi 12 jam ke-2, penyerapan tanaman bekerja pada kondisi yang optimum dalam menguraikan bahan organik yang ada pada air limbah (Sari et al., 2015). Penerapan contructed wetland dengan menggunakan aliran permukaan vertikal berkontribusi dalam menghilangkan polutan, namun semua itu tergantung pada distribusi kontaminan antara fase larut dan partikulat yang mengarah kepada penyimpanan logam dan Hidrokarbon aromatik polisiklik (PAH) (Schmitt et al., 2015). Efisiensi kadar $\mathrm{BOD}_{5}$ pada reaktor $\mathrm{B}$ disajikan di Gambar 2.

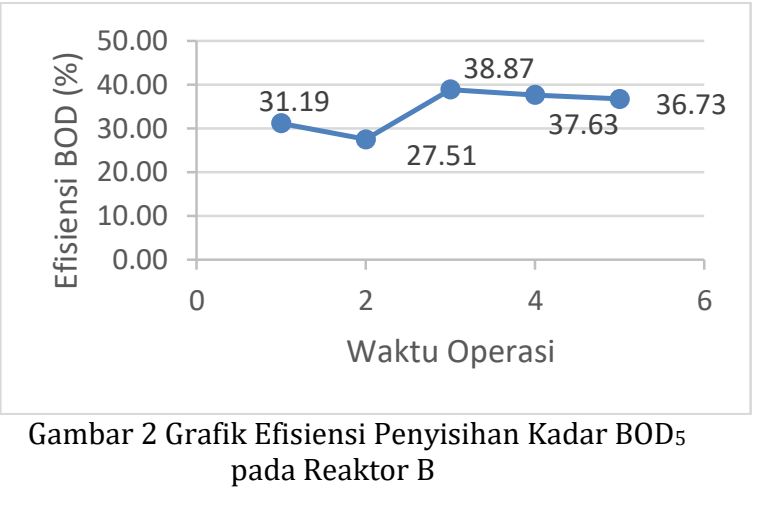

Gambar 2 menunjukan adanya penurunan kadar $\mathrm{BOD}_{5}$ tertinggi terjadi pada waktu operasi 18 jam ke-3 dengan efisiensi penyisihan sebesar 38,87\%. Jika dilihat pada Gambar 2 dan 3 diketahui waktu tinggal 18 jam mampu menurunkan kadar BOD $_{5}$ lebih tinggi dibandingkan waktu tinggal 12 jam. Penelitian yang dilakukan oleh (Sukmawati \& Pungut, 2014) diketahui efisiensi penyisihan kadar $\mathrm{BOD}_{5}$ pada air limbah domestik rumah sakit yang menggunakan media pasir dengan waktu tinggal 2 hari sebesar $59 \%$. Sedangkan wetland laut diakui sebagai beberapa sumber daya alam paling berharga di dunia, dan mereka mendukung keduanya sebagai kesejahteraan manusia dan ekonomi sosial (Barbier EB et al., 2011; Costanza et al., 2008; Walters et al., 2008). Berikutnya efisiensi kadar $\mathrm{BOD}_{5}$ pada reaktor $\mathrm{C}$ dapat dilihat pada Gambar 3. 


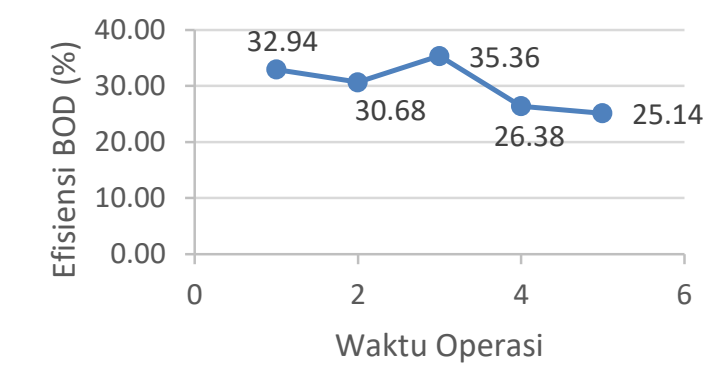

Gambar 3 Grafik Efisiensi Penyisihan Kadar BOD 5 pada Reaktor C

Berdasarkan Gambar 3 dapat dilihat bahwa efisiensi penyisihan kadar $\mathrm{BOD}_{5}$ tertinggi terjadi pada waktu operasi 12 jam ke-3 dengan efisiensi penyisihan sebesar $35,36 \%$. Penggunaan wetland dengan sistem pengolahan terapung yang dipasang secara paralel mampu meningkatkan efisiensi penghilangan kadar Phospor sebesar 27\% leih rendah jika dibandingkan dengan kolam konvensional (Borne, 2014). Efisiensi kadar $\mathrm{BOD}_{5}$ pada reaktor $\mathrm{D}$ dapat dilihat pada Gambar 4.

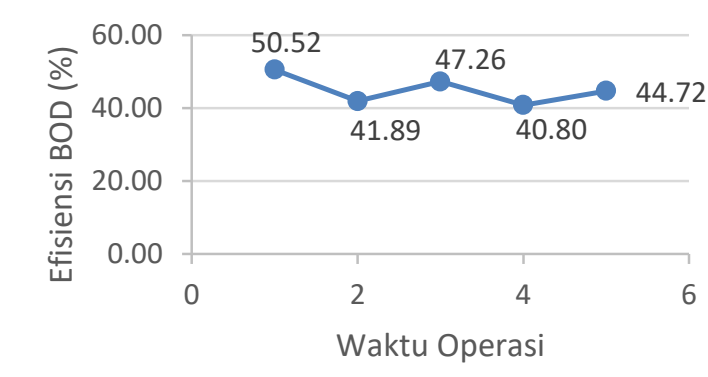

Gambar 4 Grafik Efisiensi Penyisihan Kadar BOD 5 pada Reaktor D

Dari Gambar 4 dapat dilihat bahwa efisiensi penyisihan kadar $\mathrm{BOD}_{5}$ tertinggi terjadi pada waktu operasi 18 jam ke-1 dengan efisiensi penyisihan sebesar 50,52\%. Berdasarkan penelitian yang dilakukan (Vijay et al., 2017), yaitu aplikasi constructed wetland menggunakan tanaman Typha latifolia dalam menurunkan kadar BOD 5 air limbah domestik menggunakan media campuran biochar dan tanah dengan waktu tinggal 24 jam mampu menurunkan kadar BOD $_{5}$ dengan efisiensi sebesar 95\%. Perbedaan efisiensi ini dikarenakan beban pencemar $\mathrm{BOD}_{5}$ mencapai 1513,5-2821,4 mg/L. Adapun efisiensi kadar COD pada reaktor A dapat dilihat pada Gambar 5.

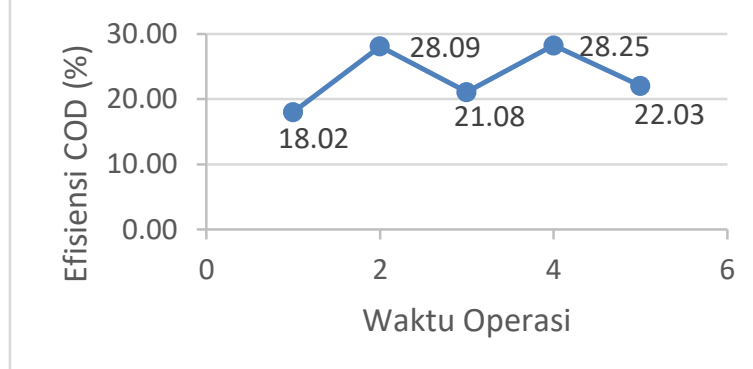

Gambar 5 Grafik Efisiensi Penyisihan Kadar COD pada Reaktor A

Berdasarkan Gambar 5 dapat dilihat bahwa efisiensi penyisihan kadar COD tertinggi terjadi pada waktu operasi 12 jam ke-4 dengan efisiensi penyisihan sebesar 28,25\%. Penggunaan contructed wetland untuk mengolah kadar COD pada stromwater dari jaringan selokan terpisah pada daerah tangkapan air perkotaan di perumahan Strasbourg mampu menyisihkan COD sebesar 70-98\% (Schmitt et al., 2015). Efisiensi kadar COD pada reaktor B dapat dilihat pada Gambar 6.

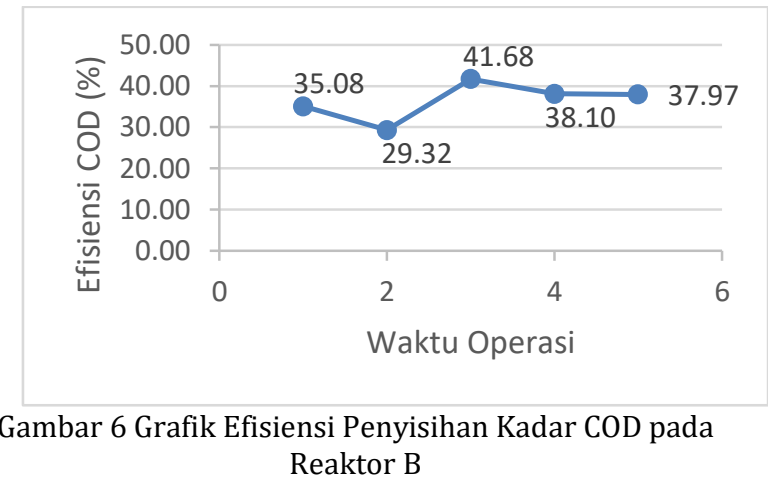

Berdasarkan Gambar 6 dapat dilihat bahwa efisiensi penyisihan kadar COD tertinggi terjadi pada waktu operasi 18 jam ke-3 dengan penyisihan sebesar 41,68\%. Jika dilihat pada Gambar 5 dan 6 diketahui waktu tinggal 18 jam mampu menurunkan kadar COD lebih tinggi dibandingkan waktu tinggal 12 jam. constructed wetland yang berbentuk parit dengan media tanam pasir kasar dan bertanaman keladi air, serta menggunakan waktu tinggal 24 jam dapat mereduksi kadar COD dengan tingkat efisiensi 57,88\%. Hal tersebut menunjukkan bahwa waktu lama waktu tinggal berpengaruh nyata terhadap efisiensi beban pencemar (Pungut \& Al Kholif, 2016). Berikutnya efisiensi kadar COD pada reaktor C dapat dilihat pada Gambar 7. 


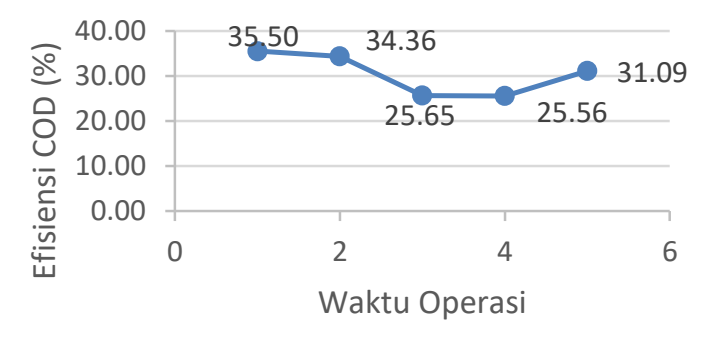

Gambar 7 Grafik Efisiensi Penyisihan Kadar COD pada Reaktor C

Berdasarkan Gambar 7 dapat dilihat bahwa efisiensi penyisihan kadar COD tertinggi terjadi pada waktu operasi 12 jam ke-1 dengan efisiensi penyisihan sebesar $35,50 \%$. Wetland membentuk ekosistem yang penting untuk menjaga kualitas lingkungan, habitat ikan dan spesies satwa liar, dan kebutuhan manusia lainny (Costanza, 2006; Tiner, 2011) Selanjutnya efisiensi kadar COD pada reaktor D dapat dilihat pada Gambar 8.

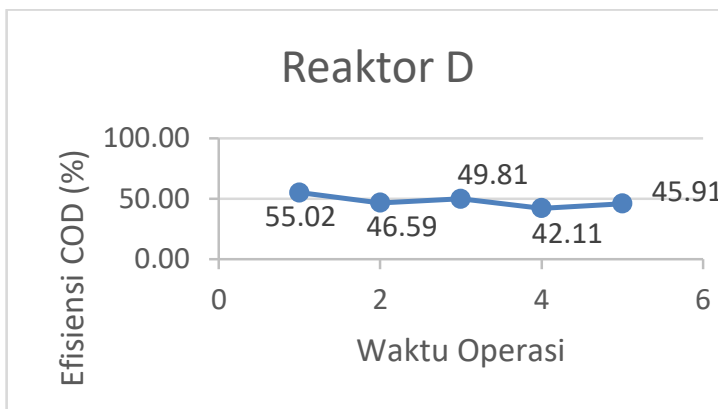

Gambar 8 Grafik Efisiensi Penyisihan Kadar COD pada Reaktor D

Berdasarkan Gambar 8 dapat dilihat bahwa efisiensi penyisihan kadar COD tertinggi terjadi pada waktu operasi 18 jam ke-1 dengan efisiensi penyisihan sebesar $55,02 \%$. Penelitian yang dilakukan (Gupta et al., 2016) menggunakan media biochar tempurung kelapa dalam waktu tinggal 3 hari diketahui efisiensi penghilangan COD sebesar 91,3\%. Nilai tersebut cukup jauh jika dibandingkan dengan hasil penelitian ini, hal itu dikarenakan waktu tinggal yang lebih lama serta debit aliran yang lebih kecil yaitu sebesar $1,2 \times 10^{-7} \mathrm{~m}^{3} /$ detik sedangkan pada penelitian ini $0,0027 \mathrm{~m}^{3} / \mathrm{jam}$.

Aplikasi constructed wetland menggunakan tanaman Typha latifolia dalam menurunkan kadar COD air limbah domestik menggunakan media campuran biochar dan tanah dengan waktu tinggal 24 jam mampu menurunkan kadar COD dengan efisiensi sebesar 86\% (Vijay et al., 2017). Hal tersebut diperkuat oleh (Nurhasmawaty, 2008) yang menyebutkan bahwa efisiensi penyisian COD menggunakan biofilter aerob dengan nilai COD awal $750 \mathrm{mg} / \mathrm{L}$ dan $1000 \mathrm{mg} / \mathrm{L}$ serta waktu tinggal 9 jam berturut-turut adalah 62,36\% dan 46,15\%, sehingga semakin besar konsentrasi COD awal pada air limbah, maka efisiensi penyisihannya akan semakin kecil.

Jika dibandingkan antara reaktor dengan media pasir dan reaktor dengan media biochar, diketahui reaktor dengan media biochar mampu menurunkan kadar COD lebih tinggi dibandingkan reaktor dengan media pasir. Hal itu dikarenakan biochar memiliki struktur yang sangat berpori, yang dapat memulihkan kontaminan organik dan anorganik, serta meningkatkan pertumbuhan mikroorganisme penting dalam tanah (Gupta et al., 2016). Biochar juga dapat meningkatkan ketersediaan nutrisi, sifat fisik tanah, serta aktivitas mikroba yang diperlukan untuk tanaman (Tapani, 2018).

Penurunan kadar beban pencemar $\mathrm{BOD}_{5}$ dan COD pada air limbah industri tahu dapat terjadi karena adanya interaksi antara tanaman, media serta mikroorganime dalam air limbah. Media tanam memiliki peran penting karena berfungsi sebagai tempat menempelnya mikroorganisme, juga berperan dalam menyokong tanama air, serta membantu proses filtrasi dan menampung sedimen (Ratnawati \& Talarima, 2017). Sehingga baik jenis media maupun lama waktu tinggal sangat berpengaruh terhadap sistem constructed wetland. Selain itu tanaman melati air juga terbukti efektif dalam menurunkan beban pencemar $\mathrm{BOD}_{5}$ dan COD. Hal itu dikarenakan melati air memiliki sistem perakaran yang letaknya di dasar perairan, kuat, panjang dan menjalar sehingga sangat efektif dalam memperluas area tempat mikroorganisme melekat (Kasman et al., 2018; Sukmawati \& Pungut, 2014).

Mekanisme penurunan beban pencemar $\mathrm{BOD}_{5}$ dan COD dari limbah cair industri tahu yang diolah dengan constructed wetland disebabkan karena keberadaan mikroorganisme aerob pada system perakaran tanaman melati air dan bakteri heterotrof dalam air limbah. Penyisihan beban pencemar terjadi melalui proses fisika, kimia dan biologi yang kompleks antara media tanam, tanaman dan mikroorganisme. Tanaman melati air mendapatkan bahan organik sebagai nutrisi melalui proses dekomposisi bahan organik oleh jaringan akarnya. Bahan organik merupakan nutrisi dalam bentuk karbon, 
nitrogen dan energi. Penyediaan oksigen terjadi melalui proses fotosintesis. Akar tumbuhan di bawah permukaan air mengeluarkan oksigen dan membentuk zona rizosfer yang kaya oksigen. Oksigen dialirkan ke akar melalui batang secara difusi pada poripori daun.

\section{KESIMPULAN}

Dari penelitian yang telah dilakukan dapat disimpulkan bahwa efisiensi penurunan kadar $\mathrm{BOD}_{5}$ dan COD tertinggi terjadi pada reaktor yang menggunakan media biochar dan waktu tinggal 18 jam dengan efisiensi penyisihan sebesar $50,52 \%$ untuk $\mathrm{BOD}_{5}$ dan $55,02 \%$ untuk COD. Pemilihan jenis tanaman akan berpengaruh terhadap keberhasilan dalam mereduksi pencemar pada idustri tahu.

\section{DAFTAR PUSTAKA}

Badan Pusat Statistik (2019). Rata-Rata Konsumsi per Kapita Seminggu Beberapa Macam Bahan Makanan Penting Tahun 2007-2018.

Astuti, A. D., Lindu, M., Yanidar, R., \& Kleden, M. M. (2017). Kinerja Subsurface Constructed Wetland Multylayer Filtration Tipe Aliran VertikalDengan Menggunakan Tanaman Akar Wangi (Vetivera Zozanoides) Dalam Penyisihan BOD Dan COD Dalam Air Limbah Kantin. Penelitian Dan Karya Ilmiah, 1(2), 91-108. https://doi.org/10.25105/pdk.v1i2.1456

Barbier EB, Hacker SD, Kennedy C, Koch EW, Stier AC, \& Silliman BR. (2011). The value of estuarine and coastal ecosystem services. Ecological Monographs, 81(2)(2), 169-193.

Borne, K. (2014). Floating treatment wetland influences on the fate and removal performance of phosphorus in stormwater retention ponds. Ecological Engineering, 69, 76-82. https://doi.org/10.1016/j.ecoleng.2014. 03.062

Costanza, R. (2006). Nature: Ecosystems without commodifying them [2]. Nature, $443, \quad 749$; author reply 750. https://doi.org/10.1038/443749b

Costanza, R., Maqueo, O. P., Martinez, M. L., Sutton, P., Anderson, S. J., \& Mulder, K. (2008). Applying a Reverse Auction to Reduce Stormwater Runoff Trading Allowances for Stormwater Control: Hydrology and Opportunity Costs Office of Research and Development National Risk Management Research Laboratory Sustainable Technologies Division Sustainabl. Journal of the Human Environment, 37(4), 241-248. https://doi.org/10.1579/00447447(2008)37

Gupta, P., Ann, T. W., \& Lee, S. M. (2016). Use of biochar to enhance constructed wetland performance in wastewater reclamation. Environmental Engineering Research, 21(1), 36-44. https://doi.org/10.4491/eer.2015.067

Kasman, M., Riyanti, A., Sy, S., \& Ridwan, M. (2018). Reduksi pencemar limbah cair industri tahu dengan tumbuhan melati air (Echinodorus palaefolius) dalam sistem kombinasi constructed wetland dan filtrasi. Jurnal Litbang Industri, 8(1), 39.

https://doi.org/10.24960/jli.v8i1.3832.3 9-46

Kaswinarni, F. (2007). Kajian Teknis Pengolahan Limbah Padat Dan Cair Industri Tahu (Studi Kasus Industri Tahu Tandang Semarang, Sederhana Kendal, dan Gagak Sipat Boyolali). In Universitas Diponegoro.

Nurhasmawaty, P. (2008). Pengolahan Limbah Cair Industri Tahu dengan Proses Biofilter Aerobik. In Jurnal Teknik Kimia.

Pungut, \& Al Kholif, M. (2016). Pemanfaatan Parit Drainase Sebagai Wetland Untuk Mendegradasi Cemaran Air Limbah Domestik. Jurnal Teknik WAKTU, 14(1), 8-14.

Ratnawati, R., \& Talarima, A. (2017). Subsurface (SSF) Constructed Wetland Untuk Pengolahan Air Limbah Laundry. Teknik Waktu, 15(2), 1-6.

Sari, P., Sudarno, \& Wisnu, I. (2015). Pengaruh Jumlah Tanaman Cyperus Alternifolius Dan Waktu Tinggal Limbah Dalam Penyisihan Kadar Ammoniak, Nitrit, Dan Nitrat (Studi Kasus : Pabrik Minyak Kayu Putih). Jurnal Teknik Lingkungan, 4(2), 19.

Schmitt, N., Wanko, A., Laurent, J., Bois, P., Molle, P., \& Mosé, R. (2015). Constructed wetlands treating stormwater from separate sewer networks in a residential Strasbourg urban catchment area: Micropollutant removal and fate. Journal of Environmental Chemical Engineering, $3(4)$, 
https://doi.org/10.1016/j.jece.2015.10.0 08

Setiyanto, R. A., Darundiati, Y. H., \& Joko, T. (2016). Efektivitas Sistem Constructed Wetlands Kombinasi Malati Air (Echinodorus Palaefolius) dan Karbon Aktif Dalam Menurunkan Kadar COD (Chemical Oxygen Demand) Limbah Cair Rumah Sakit Banyumanik Semarang. Jurnal Kesehatan Masyarakat (e-Journal), 4(1), 436-441.

Statistik, B. P. (2019). Rata-Rata Konsumsi per Kapita Seminggu Beberapa Macam Bahan Makanan Penting Tahun 2007-2018.

Sukmawati, I. W. S., \& Pungut. (2014). Removal Cemaran BOD, COD, Phosphat (PO4) Dan Detergen Menggunakan Tanaman Melati Air Sebagai Metode Constructed Wetland dalam Pengolahan Air Limbah. Teknik Waktu, 12(1), 24-34.

Tapani, N. (2018). Benefits of Biochar and its Applications for Runoff Water Management Literature Review and Laboratory Report. https://www.theseus.fi/bitstream/handl e/10024/141397/Nick_Tapani.pdf?sequ ence $=1 \&$ isAllowed $=\mathrm{y}$

Tiner, R. W. (2011). Dichotomous Keys and Mapping Codes for Wetland Landscape Position, Landform, Water Flow Path, and Waterbody Type Descriptors. In Journal of Chemical Information and Modeling (Vol. 2).

https://doi.org/10.1017/CB0978110741532 4.004=1\&isAllowed $=\mathrm{y}$

Vijay, M. V., Sudarsan, J. S., \& Nithiyanantham, S. (2017). Sustainability of constructed wetlands in using biochar for treating wastewater. Rasayan Journal of Chemistry, 10(3), 1056-1061. https://doi.org/10.7324/RJC.2017.1031 738

Walters, B. B., Rönnbäck, P., Kovacs, J. M., Crona, B., Hussain, S. A., Badola, R., Primavera, J. H., Barbier, E., \& DahdouhGuebas, F. (2008). Ethnobiology, socioeconomics and management of mangrove forests: A review. Aquatic Botany, 89(2), $220-$

236.

https://doi.org/10.1016/j.aquabot.2008. 02.009

Zhang, D. Q., Jinadasa, K. B. S. N., Gersberg, R. M., Liu, Y., Ng, W. J., \& Tan, S. K. (2014). Application of constructed wetlands for wastewater treatment in developing countries - A review of recent developments (2000-2013). Journal of Environmental Management, 141, 116131.

https://doi.org/10.1016/j.jenvman.2014. 03.015

Zhang, Y. (2012). Design of a Constructed Wetland for Wastewater Treatment and Reuse in Mount Pleasant, Utah. Master Thesis, 1-98. http://digitalcommons.usu.edu/cgi/view content. cgi?article $=1232 \&$ context $=$ gradr eports 